\title{
Investigation of antioxidant and cytotoxic activities of Opuntia ficus-indica (L.) Mill. fruit extract
}

\author{
Mehmet Evren Okur ${ }^{1}$ (D), Nihal Karakaș², (D), Ayșe Esra Karadağ $\breve{g}^{4,5}$ (D), Damla Uludağ ${ }^{3}$ (D), Derya Çiçek Polat ${ }^{6}$ \\ 'Department of Pharmacology, Faculty of Pharmacy, University of Health Sciences, Uskudar, Istanbul, Turkey \\ ${ }^{2}$ Department of Medical Biology, School of Medicine, Istanbul Medipol University, Istanbul, Turkey \\ ${ }^{3}$ Regenerative and Restorative Medicine Research Center, Istanbul Medipol University, Beykoz, Istanbul, Turkey \\ ${ }^{4}$ Department of Pharmacognosy, Faculty of Pharmacy, Istanbul Medipol University, İstanbul, Turkey \\ ${ }^{5}$ Department of Pharmacognosy, Graduate School of Health Sciences, Anadolu University, Eskișehir, Turkey \\ ${ }^{6}$ Department of Pharmaceutical Botany, Faculty of Pharmacy, Ankara University, Tandoğan, Ankara, Turkey
}

ORCID IDs of the authors: M.E.0. 0000-0001-7706-6482; N.K. 0000-0002-9096-1512; A.E.K. 0000-0002-3412-0807; D.U. 00000003-0104-8420; D.C.P. 0000-0002-4331-6828.

Cite this article as: Okur ME, Karakaș N, Karadağ AE, Uludağ D, Çiçek Polat D (2019). Investigation of antioxidant and cytotoxic activities of Opuntia ficus-indica (L.) Mill. fruit extract. Istanbul J Pharm 49 (3): 154-160.

\begin{abstract}
Opuntia ficus-indica fruits are claimed to possess several health-beneficial properties. This study was carried out to determine the phytochemicals as well as to compare antioxidant activity and cell viability of the methanol extract of OFI-fruits. Antioxidant activity was evaluated by various in vitro tests such as DPPH and ABTS. LC-MS and HPLC analyses were then performed. The activity of the OFI-fruit extract on viability of U87-MG (glioblastoma multiform), HT-29 (colon cancer) and human primary fibroblast cells was investigated by determining viable cells on a luciferase based system (Cell TiterGlo; Promega; USA). The results showed that OFI-fruits were a source of antioxidant compounds. Moreover, the extract was found to have rich phenolic-flavonoid contents. Quercetin was found in the extract according to LC-MS and HPLC studies. A remarkable increased cell death in the HT-29 and U87 cell lines was detected in a concentration-dependent manner (1-10mg/mL). Among these cell lines, HT-29 responded to OFI-fruit treatment more sensitively to even the lowest dose $(1 \mathrm{mg} / \mathrm{mL})$. The results of this study showed that the $\mathrm{OFI}$-fruit has significant antioxidant capacity and leads to strong cytotoxic activity on various cancer cells. Therefore, it can be suggested that OFI-fruits may have chemo-preventive potential and can be studied further to clarify cytotoxic abilities.
\end{abstract}

Keywords: Extract, Opuntia ficus-indica, brain cancer cell line, colon cancer cell line, antioxidant

\section{INTRODUCTION}

Opuntia ficus-indica (L.) Miller (Prickly pear cactus) is located in the Mediterranean and Aegean Region and belongs to the Cactaceae family (Kabas et al. 2006). This species is known as "kaynana dili, firenk inciri, hint inciri" in Turkey (Güner et al. 2012) and as "prickly pear" elsewhere in the world. The nutritional properties of this species have long been known. In Mediterranean countries, cladodes are not typically consumed as nutrients, but the fruits are largely consumed due to natural antioxidants which are may be protective against oxidative damage (Lee et al. 2002). The fruits are used also in traditional medicine for their hypolipidemic and hypoglycemic actions (Butera et al. 2002). The phytochemical compounds of prickly pear fruits and cladodes are vitamins, carotenoids, betalains, and polyphenolic compounds which have proven biological activities and health benefits (anti-cancer, anti-diabetic, anti-inflammatory, neuroprotective effect) (Ammar et al. 2018; Mena et al. 2018). OFI is especially rich in flavonoids and phenolic compounds. Due to the high amount of these substances the prickly pear fruit has a potent antioxidant activity (Butera et al. 2002; Lee et al. 2002; 
Dok-Go et al. 2003). O. ficus-indica (OFI) has become a popular research subject in recent years because of these therapeutical and biological properties (Bouaouine et al. 2018).

Cancer, in its various types, is the uncontrolled growth of abnormal cells. . Normal cells frequently fix DNA mutations but once the repair system fails, the cells become cancerous (Abdel-Hady et al. 2018). Although many drugs have been developed for the treatment of cancers, there are concerns about the therapeutic effects and safety of these drugs. The major problem of chemotherapeutic drugs used as a standard treatment in various types of cancers is their toxicity (Carroll et al. 2012; Lee et al. 2014; Livshits et al. 2014). However, products from plants have been proven to be effective and safe in the treatment of cancers. Therefore, cancer drug discoveries are also directed to plant derived products obtained from natural plants (Demain and Vaishnav 2011; Bishayee and Sethi 2016). These products act as anti-cancer agents by interfering with the initiation, development and progression of cancer through the modulation of various mechanisms including cellular proliferation, differentiation, apoptosis, angiogenesis, and metastasis (Sreekanth et al. 2007; Rajesh et al. 2015).

The herbal products are used worldwide in the prevention and treatment of various chronic diseases, and their potential anticancer and antimutagenic effects are under current investigation (Ahmad et al. 2014). The present study aims to determine and evaluate total phenolic and total flavonoid compounds, in vitro antioxidant properties, and in vitro cytotoxic activities against U87-MG (glioblastoma multiform; brain cancer), and HT-29 (colon cancer) cell lines.

\section{MATERIALS AND METHODS}

\section{Materials}

The standard chemicals were purchased from Sigma Chemical Co. (St. Louis, MO, USA) and the HPLC-grade solvents were purchased from Merck. DPPH (1,1diphenyl-2-picryl hydrazyl radical), ABTS (2-2'azinobis(3-ethylbenzthiazoline-6-sulphonic acid), Folin-Ciocalteu reagent and methanol were purchased from Sigma-Aldrich (Germany). All other reagents and solvents used were of analytical grade.

\section{Preparation of extract samples}

OFI-fruit samples were collected from Turunç, Marmaris (Date: 04.08.17). Voucher samples were deposited in the Herbarium of the Faculty of Pharmacy at Ankara University (No: AEF 28753). The pinkish fruits were thinly cut and air-dried. Samples were powdered and extracted with methanol on a magnetic stirrer (Heidolph MR3001, Germany) (200 g sample, $200 \mathrm{ml}$ x 3) followed by filtration. The extract was distilled by the rotary evaporator (Heidolph WB2000, Germany). The yield of the extraction procedure was calculated as 8,98\% (w/w).

\section{Total phenolic and flavonoid contents of the extract}

TPC (Total phenolic content) of OFI-fruit extract was determined by Folin-Ciocalteu method. $5 \mathrm{ml}$ of extract sample was mixed with $0.2 \mathrm{ml}$ of $7.5 \% \mathrm{Na}_{2} \mathrm{CO}_{3}$ and $0.25 \mathrm{ml}$ of Folin-Ciocalteu's reagent. The mixtures were incubated for $15 \mathrm{~min}$ at $45^{\circ} \mathrm{C}$ and the absorbance was calculated at $765 \mathrm{~nm}$. TPC was determined by the calibration curve $\left(R^{2}=0.9811\right)$ (Okur et al. 2018a) and the result was expressed in terms of $\mathrm{mg}$ gallic acid equivalents (GAE) per $100 \mathrm{~g}$ (Spanos and Wrolstad 1990).

The colorimetric aluminum chloride method was utilized in order to determine TFC (Total flavonoid content) of the OFI-fruit extract. Briefly, $50 \mu \mathrm{L}$ OFl-fruit extract was diluted to $1 \mathrm{~mL}$ volume with methanol. After being added to $5 \% \mathrm{NaNO}_{2}(0.3 \mathrm{~mL})$ solution and water ( $4 \mathrm{~mL}$ ), the mixture was left for incubation ( $5 \mathrm{~min}$ ) and then a solution of $10 \% \mathrm{AlCl}_{3}(0.3 \mathrm{~mL})$ was added and the mix was kept for 6 minutes. Next, a solution of $1 \mathrm{~mol} / \mathrm{L} \mathrm{NaOH}(2 \mathrm{~mL})$ was added and the mix was made up to $10 \mathrm{~mL}$ with water. The mixture was kept for 15 minutes, and absorbance was measured spectrophotometrically at $510 \mathrm{~nm}$. TFC was measured by the calibration curve $\left(R^{2}=0.9978\right)$ (Okur et al. 2018b) and the result was expressed in terms of $\mathrm{mg}$ quercetin equivalents (QE) per $100 \mathrm{~g}$. For analysis of flavonoid and phenolic compounds studies of extract sample, three replications were performed.

\section{In vitro antioxidant assays}

\section{DPPH scavenging assay}

The antioxidant capacity of the OFl-fruit extract was determined in terms of hydrogen donating or radical scavenging ability using DPPH by its capability to bleach the stable radical (Blois 1958). The reaction mix contained $100 \mu \mathrm{M} \mathrm{DPPH}$ in methanol and several concentrations of the crude extract. After 30 minutes, absorbances were measured at $517 \mathrm{~nm}$ using an UVVis spectrophotometer (UV-1800, Shimadzu, Japan) at $25 \pm 2^{\circ} \mathrm{C}$ and the radical scavenging activity (RSA) was determined as the percentage of radical reduction. The study was performed on Ascorbic acid as the reference (Okur et al. 2018a). The outcomes were declared as IC50 as follows:

DPPH RSA \% $=[($ Absorbance control - Absorbance test sample)/Absorbance control)] $\times 100$

Each experiment was performed in triplicate. Ascorbic acid was used as the reference (Okur et al. 2018).

The DPPH test is based upon the reduction of methanolic DPPH solution in the presence of hydrogen do-nating antioxidants through the formation of non-radical form (DPPH-H) (Lee et al. 2012).

\section{ABTS radical scavenging assay}

The antioxidant capacity of OFI-fruit extract was evaluated by the ABTS radical cation decolorization test (Re et al. 1999). ABTS solution was prepared by mixing aqueous ABTS (7 mM) and potassium persulfate $(2.45 \mathrm{mM})$. The mixture was stored for $12-16 \mathrm{~h}$ in the dark at $25 \pm 2^{\circ} \mathrm{C}$. To regulate its absorbance at $734 \mathrm{~nm}$, this final solution was diluted with ethanol and the percent inhibition was calculated. The test was carried out in triplicate. To determine absorbance of the extract, $990 \mu \mathrm{L}$ ethanol was used instead of ABTS in the control. The study was performed on Trolox as the reference (Okur et al. 2018b). The results were expressed as $\mathrm{IC}_{50}$ as follows:

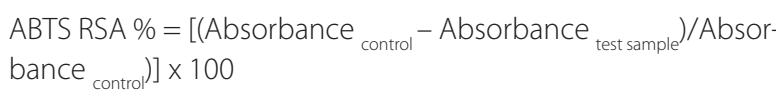

\section{Extraction for LC-MS and HPLC analysis}

For Liquid Chromatography Mass Spectroscopy (LC-MS) analysis $5 \mathrm{mg}$ methanol extract of OFl-fruit was dissolved in $5 \mathrm{~mL}$ 
ethanol and filtered by $0.22 \mu \mathrm{m}$ membrane filters. Also, the same sample was used for High Pressure Liquid Chromatography (HPLC) analysis.

\section{Qualitative and quantitative chromatographic analysis with LC-MS and HPLC systems}

Methanol extract of OFI-fruit was analysed using LC-MS on a single quadrupole mass spectrometer (1200 LC, Agilent). For the chromatropic separation, LC-MS was run on an Agilent $4.6 \times 250$ mm, $5 \mu \mathrm{m}$ particle size, octadecyl silica gel C18 analytical column and its temperature was maintained at $40^{\circ} \mathrm{C}$. The elution gradient which consisted of mobile phases were $A$ (Acetonitrile: Water: Formic acid (10:89:1, v/v/v)) and B (Acetonitrile: Water: Formic acid (89:10:1, v/v/v)). The gradient elution was established in the time frame 0-40 min, B\% 15-100. The solvent flow rate was maintained at $0.7 \mathrm{ml} / \mathrm{min}$. The injection volume was $20 \mu \mathrm{L}$ (Gulsoy-Toplan et al. 2018).

Quercetin concentration in OFl-fruit methanol extract was determined using HPLC technique. The HPLC analysis was performed on an Agilent 1200 series instrument. The analytical HPLC column was Agilent C18 column of $5 \mu \mathrm{m}$ particle size and $4.6 \mathrm{~mm} \times 250 \mathrm{~mm}$ dimensions. LC-MS mobil phase was used. A reference standard of quercetin was prepared from the USP. The flow rate was set to $0.7 \mathrm{~mL} / \mathrm{min}$; injection volume and column temperature were adjusted to $20 \mu \mathrm{L}$ and $40^{\circ} \mathrm{C}$, respectively. The detection was performed at $330 \mathrm{~nm}$ (Gulsoy-Toplan et al. 2018). The HPLC method was validated based on the experimental results; linearity, selectivity, LOD, LOQ, accuracy, precision, RSD, recovery and robustness (Üstündağ-Okur et al. 2015; Okur et al. 2018b). The quercetin concentration in each extract was calculated by the following regression equation $y=$ $59671 x-18,47$ with good linearity $\left(r^{2}=0.9996\right)$. All standard and sample solutions were injected in triplicate.

Table 1. TPC and TFC contents of OFI-fruit extract

\begin{tabular}{|lcc|}
\hline & $\begin{array}{cc}\text { TPC } \mathrm{mg} \text { GAE/ } \\
100 \mathrm{~g} \text { Extract }\end{array}$ & $\begin{array}{c}\text { TFC } \mathrm{mg} \text { QE/ } \\
100 \mathrm{~g} \text { Extract }\end{array}$ \\
\hline OFI Fruit Extract & $363.20 \pm 0.02$ & $1490.34 \pm 0.05$ \\
\hline TPC: Total phenolic; TFC: total flavonoid & \\
\hline
\end{tabular}

Table 2. DPPH and ABTS scavenging activities of OFI-fruit methanol extract

\begin{tabular}{|lcc|}
\hline & OFI Fruit Extract & References \\
\hline \multicolumn{3}{|c|}{ IC50 \pm SD $(\mathrm{mg} / \mathrm{mL}$ ) } \\
\hline DPPH & $4.12 \pm 0.03$ & $4.67 \pm 0.04$ (Ascorbic acid) \\
ABTS & $2.46 \pm 0.04$ & $3.84 \pm 0.04$ (Trolox) \\
\hline
\end{tabular}

Table 3. Determined flavonoids of OFI-fruit methanol extract by LC-MS

\begin{tabular}{|lccc|}
\hline Compound & RT & Area & Base Peak $(\mathrm{m} / \mathbf{z})$ \\
\hline Myrcetin & 11.436 & 6268 & 316.93 \\
Quercetin & 15.250 & 6926446 & 301.02 \\
Luteolin & 19.153 & 39288 & 285.03 \\
\hline
\end{tabular}

\section{Cell culture}

U87-MG (glioblastoma multiform; brain cancer), HT-29 (colon cancer) and human primary fibroblast ((HDFa) ATCC ${ }^{\circ}$ PCS-201012) were purchased from ATCC (U.S.). The cells were cultured in growth medium either DMEM (U87-MG, Human primary fibroblast) or RPMI (HT-29,Gibco) medium each with 10\% fetal bovine serum (Gibco), 1\% antibiotic (penicillin/streptomycin) at $37^{\circ} \mathrm{C}$ in $5 \% \mathrm{CO}_{2}$ incubator. Confluent cells were then removed from the flask with trypsin/EDTA (Gibco) and seeded into 96 well plates for viability assays.

\section{Cell viability assay}

Cells were plated in 96 well plates at a density of $5 \times 10^{3}$ cells/ well for cell viability assays (luciferase based Cell Titer Glo Assay: Promega) and incubated for $24 \mathrm{~h}$ at $37^{\circ} \mathrm{C}$ in $5 \% \mathrm{CO}_{2}$ incubator. The extract was dissolved in dimethylsulfoxide (DMSO) and filtered to prepare stock solutions, and then serial dilutions were made using growth mediums considering 0.5\% DMSO threshold for cellular toxicity. Then the medium was aspirated from all wells and treated with the OFI-fruit extract at a concentration range between 1-10 mg/mL. Accordingly, to normalize the measurements, control cells were treated with DMSO for each dose accordingly. All treatments were performed as triplicates. After $48 \mathrm{~h}$, the medium was removed and Cell Titer Glo reagent (Promega) was applied to the wells and measurements of metabolically active cells were determined using SpectraMax i3x Multi-Mode Detection Platform (Sittampalam et al. 2004, Rodenhizer et al. 2018, Zhang et al. 2018).

\section{Statistical analysis}

For cell viability assays, statistical comparisons were performed by unpaired Student's t-test assuming equal variance. Differences were considered as statistically significant at $0.001<p^{*}<0.05$ and $p^{* *}<0.005$. Data are the mean \pm standard error of the mean (S.E.M.).

\section{RESULTS}

\section{Total phenolic and flavonoid contents of the extract}

TPC and TFC of the OFI-fruit extract were determined. The Folin-Ciocalteu method is a widespread assay which is used for quantitative determination of phenolic compounds. Table 1 shows the total phenolic and flavonoid contents. OFI-fruit extract contained a significantly high antioxidants content (363.20 0.02 GAE/100g extract).

\section{In vitro antioxidant assays}

Detection of antioxidant capacity of the OFI-fruit extract is given in Table 2. According to the DPPH test results, antioxidant activity of OFI fruit extract was found as $4.12 \pm 0.03 \mathrm{mg} / \mathrm{mL}$ and according to other (ABTS) test results, OFI fruit extract as $2.46 \pm 0.04 \mathrm{mg} / \mathrm{mL}$.

\section{Qualitative-quantitative chromatographic analysis by LC-MS and HPLC}

The flavonoid contents of the methanol extract were detected by HPLC and LC/MS analyses. Standards were detected in accordance with quantitative and mass analyses using reversedphase chromatography. Quercetin (2-(3,4-dihydroxyphenyl)3,5,7-trihydroxychromen-4-one) was identified in the methanol 
extract as major flavonoid component. Additionally, myrcetin and luteolin were detected in the extract as flavonoids. The LCMS chromatogram of the methanol extract is shown in Table 3.

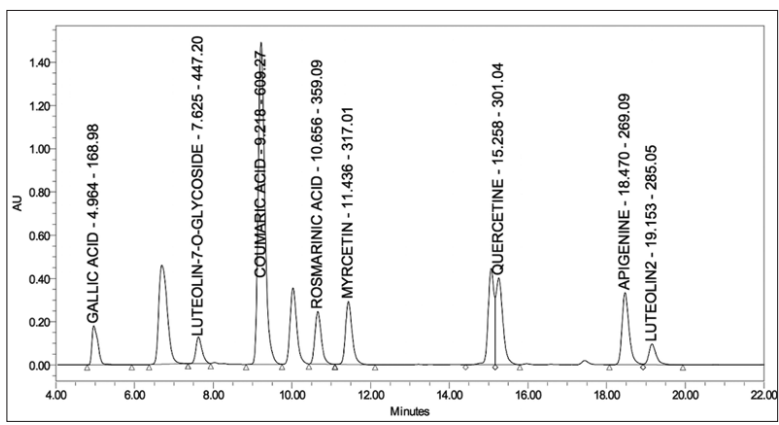

Figure 1. LC-MS standard chromatogram. Standards: 1, Gallic acid (R.T. 4,96); 2, Luteolin-7-o-glycoside (R.T. 7,62); 3, Coumaric acid (R.T. 9,21); 4, Rosmarinic acid (R.T. 10,65); 5, Myrcetin (R.T. 11,43); 6, Quercetin (R.T. 15,25); 7, Apigenine (R.T. 18,47); 8 Luteolin (R.T. 19,15) (R.T.=Retantion time).

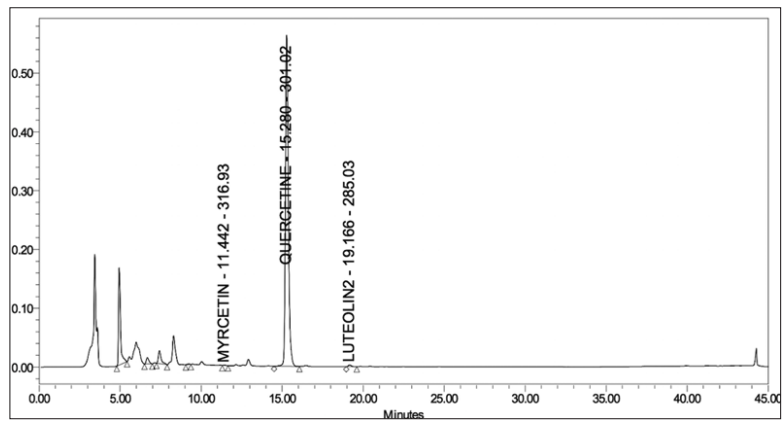

Figure 2. OFI-fruit metanol extract LC-MS chromatogram.

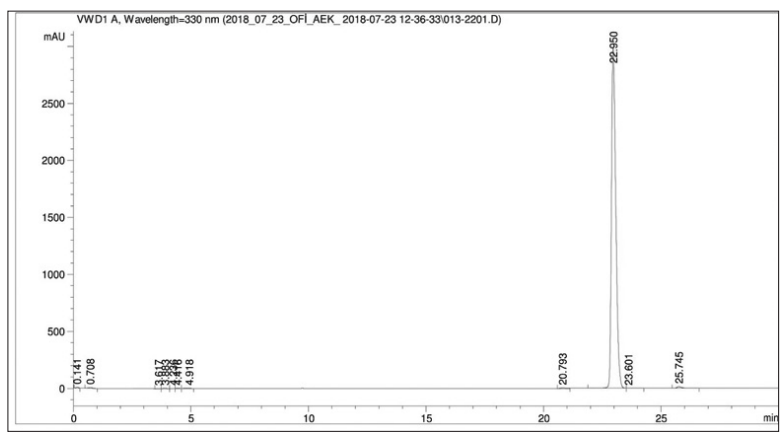

Figure 3. Quercetin Standard chromatogram. Quercetin (R.T. 22,86).

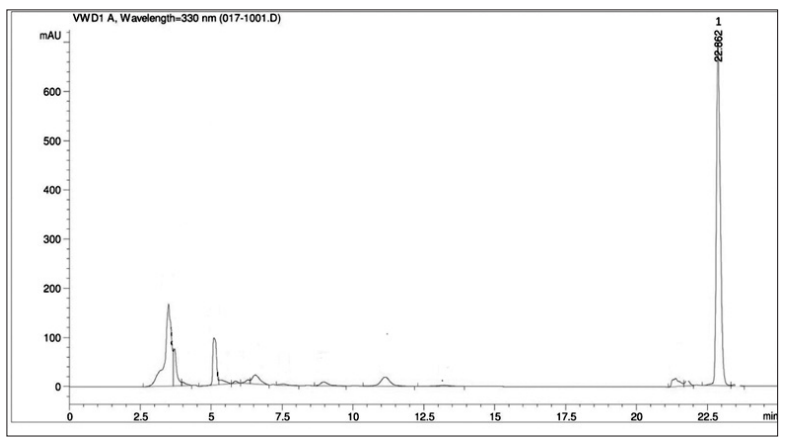

Figure 4. OFI-fruit methanol extract HPLC Chromatogram. 1, Quercetin (R.T. 22,86).22,86).
Determined flavonoids of OFI-fruit methanol extract by LC-MS were given in Figure 1. Figure 2 shows OFI-fruit extract LC-MS chromatogram.

Quercetin amounts in the methanol extract was examined by HPLC (Figures 3 and 4). Additionally, the HPLC method was validated according to the experimental results of quercetin: linear range (0.02-0.0015 mg/ml); recovery (99.82 +3.97\%); LOD (0.0006 mg/mL); LOQ (0.0015 mg/mL) and RSD (6.16\%). The extract has $0.401 \pm 0.012 \%$ amount of quercetin.

\section{Cell viability}

The OFI-fruit extract $(1-10 \mathrm{mg} / \mathrm{mL})$ showed significant cytotoxic effects on HT-29 (colon) and U87 (brain) cancer cell lines while the extract was not cytotoxic for human primary fibroblast at the same concentrations (Figure 5. a-c.). Cytotoxicity of the OFI-fruit extract on U87, HT-29 cancer cell lines and human primary fibroblast (as healthy control) was analyzed by measuring cell viability based on their metabolically active state. According to the obtained results, the OFI-fruit extract resulted in a significantly increased cell death in the HT-29 (colon cancer) and U87 (brain cancer) between the concentration range of $1-10 \mathrm{mg} / \mathrm{mL}$ in a concentration dependent manner. Among these cell lines, HT-29 responded to OFI-fruit extract treatment more sensitively even at the lowest dose $(1 \mathrm{mg} / \mathrm{mL})$. On the other hand, $5 \mathrm{mg} / \mathrm{ml}$ treatment with OFI-fruit extract was sig-

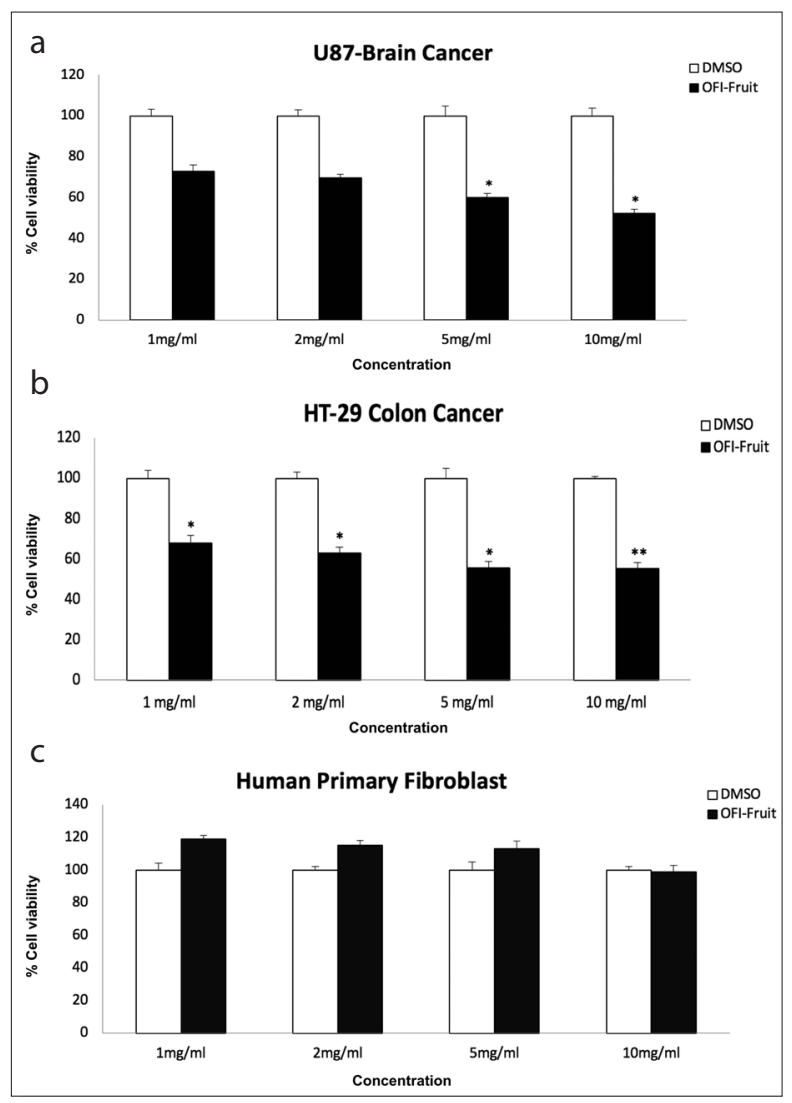

Figure 5. a-c. Cell viability of a) U87 (brain cancer) cell line, b) HT-29 (colon cancer) cell line, c) human primary fibroblast (normal cell) cell line upon 48 hours treatment with 1-10 mg/ $\mathrm{mL}$ OFI-fruit extracts. Data are expressed as the mean \pm SEM $\left(0.001<p^{*}<0.05\right.$ and $\left.p^{* *}<0.005\right)$. 
nificantly toxic to U87 cell line and cell death increased when treated with $10 \mathrm{mg} / \mathrm{mL}$ extract.

\section{DISCUSSION}

Cancer is a major public health problem in the world. In recent years, the use of herbal medicines in cancer treatment has received increasing attention due to their varied phytometabolic contents with multiple biological activities (Mann 2002). In our study, TPC of OFI-fruit extract was determined by Folin-Ciocalteu method. TPC of OFI-fruit extract was determined as $363.20 \pm 0.02 \mathrm{GAE} / 100 \mathrm{~g}$ extract. The phenolic and flavonoid compounds are the major ingredients of various plants. It has been stated that these compounds possess protective and therapeutic activities to heal various diseases due to their hydroxyls groups which are responsible for the free radical scavenging activity (Abdel-Hady et al. 2018). OFI is rich in flavonoid and phenolic compounds and therefore it has high antioxidant activity (Lee et al. 2002). Flavonoids belong to secondary plant metabolites with a polyphenolic structure, which is commonly found in fruits and vegetables. They have various significant biochemical effects such as antioxidative, anti-inflammatory, antimicrobial, antithrombogenic, antimutagenic and anticarcinogenic activities (Panche et al. 2016). More than 5000 naturally occurring flavonoids have already been identified. The outcomes displayed in Table I show that the OFl-fruit extract exhibit high flavonoid and phenolic contents.

Antioxidants play an important role in neutralizing free radical species which are produced as end or by-products of normal biochemical reactions in a normal system (Jiménez-Estrada et al. 2013). Oxidative stress causes many diseases (cardiovascular diseases, diabetes, cancer, alzheimer etc.). Current studies about free radicals have supported that antioxidant rich-foods display a leading role in the prevention of cancers. Therefore, much interest has been focused on the benefit of natural antioxidants to keep protection against free radicals which cause damage (Lee et al. 2012). Many methods of analysis have been developed for in vitro and in vivo antioxidant activity. However, there are only a few reliable and fast methods for the evaluating of the antioxidant capacity of plant extracts. Total antioxidant activity tests, such as DPPH and ABTS, is most common for large-scale examination (Cai et al. 2004). In the present work the antioxidant capacity of OFI-fruit extract was evaluated by the DPPH and ABTS techniques. The antioxidant capacity of OFl-fruit extract was found as $2.46 \pm 0.04 \mathrm{mg} / \mathrm{mL}$ while trolox was determined as $3.84 \pm 0.04 \mathrm{mg} / \mathrm{mL}$ with ABTS method. Accoring to the DPPH method, antioxidant capacity of OFI-fruit extract was found as $4.12 \pm 0.03 \mathrm{mg} / \mathrm{mL}$. Many studies have shown that plant components can be effective and protective against oxidative damage (Butera et al. 2002; Lee et al. 2002). Several phenolics such as phenolic acids, flavonoids, coumarins, curcuminoids, lignans, quinones, stilbenes, etc. possess potent antioxidant capacity as well as potential anti-cancer activity, (Sun et al. 2002; Cai et al. 2004).

Prior research has reported the relationship between antioxidant activity and TPC (Sun et al. 2002; Cai et al. 2004). Quercetin is one of the most prominent antioxidants, which is a member of the flavonoids family. It has favourable biochemi- cal activity. Most of the anti-cancer agents have been shown to possess antioxidant potential that can play an important role in the protection of some forms of cancer (Khanapur et al. 2014). Quercetin has perfect antioxidant activity. It is the most effective scavenger of ROS (Boots et al. 2008) and also previous studies have shown that quercetin, myricetin and luteolin have anti-cancer activity (Lu et al. 2006; Chahar et al. 2011; Majumdar et al. 2014; Rauf et al. 2018; Sun et al. 2018). The total phenolic compounds and flavonoids which are responsible for antioxidant activity were also rich in fruits. By LC-MS analysis, 3 flavonoids were determined (Myrcetin, Quercetin and Luteolin) (Table III) and quercetin compound was also found to be rich in methanol extract of OFI-fruits.

The evaluation of the anti-cancer activity of plant extracts is essential for safe treatment. Various anti-cancer activity studies with cell lines used in this study are available on plant extracts (Okur et al. 2019). OFI fruits are also in the safe range in terms of toxicity because they are consumed as food among the public. OFl-fruit extract was analyzed for potential in vitro cytotoxic effects by using cancer cell lines from different tissue origins including colon and brain cancers. DMSO was used as the control group, and the $\mathrm{IC}_{50}$ value from this group was set as the background. In this present study, OFI fruit extract was shown to have selectivity against the HT-29 and U87 cancer cell lines with $4.386 \mathrm{mg} / \mathrm{mL}, 5.297 \mathrm{mg} / \mathrm{mL} \mathrm{IC}_{50}$ values, respectively. It can be said that our study is the first which evaluates the cytotoxic effects of 0 . ficus-indica plant extracts in the specific cell lines, since previous conducted studies evaluated cytotoxicity in different cancer lines. More specifically, OFI plant has shown positive results, according to previous studies which have been conducted against ovarian and cervical cancer cell lines (Kaur et al. 2012). El-Beltagi et al. studied the anticancer activities of OFI peel and pulp extracts on Liver (HepG2), colorectal adenocarcinoma (Caco-2) and Breast (MCF-7) cell lines. OFI peel and pulp extracts were tested at $3 \mathrm{mg} / \mathrm{mL}$ and decreasing doses and a decrease in growth of cancer cells was observed at high doses (El-Beltagi et al. 2019). In another previous study prickly pear cactus seed oil was studied for its anti-cancer activity against colon cancer cell lines. As a result, cell viability has been observed significantly in some colon cancer cell lines (Becer et al. 2018). In addition, the anti-cancer activity of indicaxanthin, which is known to be highly present in the fruits of O. ficus-indica, on melanoma cancer was investigated by in vivo and in vitro methods and very successful results were obtained (Allegra et al. 2018). In this study, an increasing activity was observed in increasing doses as well as selectivity. In conclusion, OFI-fruit extracts were significantly toxic to HT-29 (colon cancer) cells even at the lowest dose $1 \mathrm{mg} / \mathrm{mL}$ while U87 (glioblastoma brain cancer) cells showed significantly increased cell death upon treatment with $5 \mathrm{mg} / \mathrm{mL}$ extract and viability decreased on both lines in a dose dependent manner. It can be said that $10 \mathrm{mg} / \mathrm{mL}$ of OFl-fruit extract was cytotoxic to all the cancer cell lines tested. Different cytotoxic efficacies to OFI-fruit extract might be linked to diverse mutagenic profiles of the cancer cell lines which facilitate their escape from cell death mechanisms. To sum up, this study demonstrates that OFI-fruit extract has significant cytotoxic effects on cancer cell lines from different origins such as colon (HT-29) and 
brain (U87) cancers and is found to be promising to extensively study cytotoxic activities of OFI extracts that can shed light on underlying mechanisms.

\section{CONCLUSION}

In this study, total phenolic compounds and total flavonoid contents of OFI fruits were determined and they were studied in respect to their antioxidant and cytotoxic activities. The flavonoid contents of the extracts revealed HPLC and LC-MS. Cytotoxicity of OFI-fruit extract was measured by determining in vitro cell viability of different cancer cell lines composed of brain (U87-MG), colon (HT-29) and human primary fibroblast upon treatment with OFI-fruit extract. According to cell viability assays, the OFI-fruit extract showed a significant cytotoxic effect (more potently at the $10 \mathrm{mg} / \mathrm{mL}$ dose) on both U87-MG, HT-29 and human primary fibroblast. Further studies are required to isolate cytotoxic compounds.

Peer-review: Externally peer-reviewed.

Author Contributions: Concept - M.E.O., N.K.; Design - M.E.O.; Supervision - M.E.O., N.K.; Resource - M.E.O., N.K.; Materials - M.E.O., N.K., A.E.K., D.Ç.P.; Data Collection and/or Processing - M.E.O., N.K., A.E.K., D.U., D.Ç.P.; Analysis and/or Interpretation - M.E.O., N.K., A.E.K., D.Ç.P.; Literature Search - M.E.O., N.K., D.C..P.; Writing - M.E.O., N.K., A.E.K.; Critical Reviews - M.E.O., N.K.

Conflict of Interest: The authors have no conflict of interest to declare.

Financial Disclosure: The authors declared that this study has received no financial support.

\section{REFERENCES}

- $\quad$ Abdel-Hady H, Mohamed El-Sayed M, Mohamed Abdel-Gawad M, Ahmed El-Wakil E, Saleh Abdel-Hameed E-S, El-Sayed AbdelLateef E (2000). LC-ESI-MS analysis, antitumor and antioxidant activities of methanolic extract of Egyptian Allium kurrat. J Appl Pharm Sci 8: 85-92. [CrossRef]

- $\quad$ Ahmad MS, Ahmad S, Arshad M, Rai KB, Afzal M (2014). Terminalia catappa, an anticlastogenic agent against MMS induced genotoxicity in the human lymphocyte culture and in bone marrow cells of Albino mice. Egypt J Med Hum Genet 15: 227-233. [CrossRef]

- Allegra M, De Cicco P, Ercolano G, Attanzio A, Busà R, Cirino G, lanaro A (2018). Indicaxanthin from Opuntia Ficus Indica (L. Mill) impairs melanoma cell proliferation, invasiveness, and tumor progression. Phytomedicine 50: 19-24. [CrossRef]

- Ammar I, Ben Salem M, Harrabi B, Mzid M, Bardaa S, Sahnoun Z (2018). Anti-inflammatory activity and phenolic composition of prickly pear (Opuntia ficus-indica) flowers. Ind Crops Prod 112: 313-319. [CrossRef]

- Becer E, Kabadayı H, Meriçli F, Meriçli AH, Kıvançlı B, Vatansever S (2018). Apoptotic Effects of Opuntia ficus indica L. Seed Oils on Colon Adenocarcinoma Cell Lines. In MDPI 2: 1566. [CrossRef]

- Bishayee A, Sethi G (2016). Bioactive natural products in cancer prevention and therapy: Progress and promise. Semin Cancer Biol 40-41: 1-3. [CrossRef]

- Blois MS (1958). Antioxidant determinations by the use of a stable free radical. Nature 181: 1199-1200. [CrossRef]

- Boots AW, Haenen GRMM, Bast A (2008). Health effects of quercetin: From antioxidant to nutraceutical. Eur J Pharmaco/ 585: 325337. [CrossRef]
Bouaouine O, Bourven I, Khalil F, Baudu M (2018). Identification of functional groups of Opuntia ficus-indica involved in coagulation process after its active part extraction. Environ Sci Pollut Res (11): 11111-11119. [CrossRef]

- Butera D, Tesoriere L, Di Gaudio F, Bongiorno A, Allegra M, Pintaudi AM (2002). Antioxidant activities of sicilian prickly pear (Opuntia ficus indica) fruit extracts and reducing properties of its betalains: Betanin and indicaxanthin. J Agric Food Chem 50: 68956901. [CrossRef]

Cai Y, Luo Q, Sun M, Corke H (2004). Antioxidant activity and phenolic compounds of 112 traditional Chinese medicinal plants associated with anticancer. Life Sci 74: 2157-2184. [CrossRef]

- Carroll J, Protani M, Walpole E, Martin JH (2012). Effect of obesity on toxicity in women treated with adjuvant chemotherapy for early-stage breast cancer: a systematic review. Breast Cancer Res Treat 136: 323-330. [CrossRef]

- Chahar M, Sharma N, Dobhal M, Joshi Y (2011). Flavonoids: A versatile source of anticancer drugs. Pharmacogn Rev 5: 1. [CrossRef] Demain AL, Vaishnav P (2011). Natural products for cancer chemotherapy. Microb Biotechno/ 4: 687-699. [CrossRef]

- Dok-Go H, Lee KH, Kim HJ, Lee EH, Lee J, Song YS (2003). Neuroprotective effects of antioxidative flavonoids, quercetin, (+)-dihydroquercetin and quercetin 3-methyl ether, isolated from Opuntia ficus-indica var. saboten. Brain Res 965: 130-136. [CrossRef]

El-Beltagi HS, Mohamed HI, Elmelegy AA, Eldesoky SE, Safwat, G (2019). Phytochemical Screening, Antimicrobial, Antioxidant, Anticancer Activities And Nutritional Values Of Cactus (Opuntia Ficus Indicia) Pulp And Peel. Fresen Environ Bull 28: 1545-1562.

Gulsoy-Toplan G, Goger F, Yildiz-Peko A, Gibbons S, Sariyar G, Mat A (2018). Chemical Constituents of the Different Parts of Colchicum micranthum and C. chalcedonicum and their Cytotoxic Activities. Nat Prod Commun 13: 535-538. [CrossRef]

- Güner A, Aslan S, Ekim T, Vural M, Babac MT, Yıldırım H. Turkey Plant List (Vascular Plants). İstanbul: Nezahat Gökyiğit Botanic Park Press; 2012.

- Jiménez-Estrada M, Velázquez-Contreras C, Garibay-Escobar A, Sierras-Canchola D, Lapizco-Vázquez R, Ortiz-Sandoval C (2013). In vitro antioxidant and antiproliferative activities of plants of the ethnopharmacopeia from northwest of Mexico. BMC Complement Altern Med 13: 12. [CrossRef]

Kabas O, Ozmerzi A, Akinci I (2006). Physical properties of cactus pear (Opuntia ficus india L.) grown wild in Turkey. J Food Eng 73: 198-202. [CrossRef]

- Kaur M, Kaur A, Sharma R (2012). Pharmacological actions of Opuntia ficus indica: A Review. J Appl Pharm 2: 15-18. [CrossRef] Khanapur M, Avadhanula RK, Setty OH (2014). In vitro antioxidant, antiproliferative, and phytochemical study in different extracts of Nyctanthes arbortristis flowers. Biomed Res Int 2014: 291271. [CrossRef]

Lee CS, Ryan EJ, Doherty GA (2014). Gastro-intestinal toxicity of chemotherapeutics in colorectal cancer: the role of inflammation. World J Gastroentero/ 20: 3751-3761. [CrossRef]

Lee J-C, Kim H-R, Kim J, Jang Y-S (2002). Antioxidant property of an ethanol extract of the stem of Opuntia ficus-indica var. saboten. J Agric Food Chem 50: 6490-6496. [CrossRef]

Lee WC, Mahmud R, Pillai S, Perumal S, Ismail S (2012). Antioxidant Activities of Essential Oil of Psidium Guajava L. Leaves. APCBEE Procedia 2: 86-91. [CrossRef]

Livshits Z, Rao RB, Smith SW (2014). An Approach to Chemotherapy-Associated Toxicity. Emerg Med Clin North Am 32: 167-203. [CrossRef]

Lu J, Papp L V., Fang J, Rodriguez-Nieto S, Zhivotovsky B, Holmgren A (2006). Inhibition of Mammalian Thioredoxin Reductase 
by Some Flavonoids: Implications for Myricetin and Quercetin Anticancer Activity. Cancer Res 66: 4410-4418. [CrossRef]

- Majumdar D, Jung K-H, Zhang H, Nannapaneni S, Wang X, Amin ARMR (2014). Luteolin Nanoparticle in Chemoprevention: In Vitro and In Vivo Anticancer Activity. Cancer Prev Res 7: 65-73. [CrossRef]

- Mann J (2002). Natural products in cancer chemotherapy: past, present and future. Nat Rev Cancer 2: 143-148. [CrossRef]

- Mena P, Tassotti M, Andreu L, Nuncio-Jáuregui N, Legua P, Del Rio D (2018). Phytochemical characterization of different prickly pear (Opuntia ficus-indica (L.) Mill.) cultivars and botanical parts: UHPLC-ESI-MS n metabolomics profiles and their chemometric analysis. Food Res Int 108: 301-318. [CrossRef]

- Okur ME, Ayla Ş, Çiçek Polat D, Günal MY, Yoltaş A, Biçeroğlu Ö (2018a). Novel insight into wound healing properties of methanol extract of Capparis ovata Desf. var. palaestina Zohary fruits. J Pharm Pharmacol 70: 1401-1413. [CrossRef]

- $\quad$ Okur ME, Karakaş N, Karadag AE, Yılmaz R, Demirci F (2019). In vitro cytotoxicity evaluation of Marrubium vulgare $\mathrm{L}$. methanol extract. J Res Pharm 23: 711-718. [CrossRef]

- Okur ME, Polat DC, Ozbek H, Yilmaz S, Yoltas A, Arslan R (2018b). Evaluation of the antidiabetic property of capparis ovata desf. Var. Paleastina zoh. Extracts using in vivo and in vitro approaches. Endocrine, Metab Immune Disord - Drug Targets 18: 489-501. [CrossRef]

- $\quad$ Panche AN, Diwan AD, Chandra SR (2016). Flavonoids: an overview. J Nutr Sci 5:e47. [CrossRef]

- $\quad$ Rajesh E, Sankari L, Malathi L, Krupaa J (2015) Naturally occurring products in cancer therapy. J Pharm Bioallied Sci 7: 183. [CrossRef]

- Rauf A, Imran M, Khan IA, ur-Rehman M-, Gilani SA, Mehmood $Z$ (2018). Anticancer potential of quercetin: A comprehensive review. Phyther Res 32: 2109-2130. [CrossRef]
Re R, Pellegrini N, Proteggente A, Pannala A, Yang M, Rice-Evans C (1999). Antioxidant activity applying an improved ABTS radical cation decolorization assay. Free Radic Biol Med 26: 1231-1237. [CrossRef] Rodenhizer D, Dean T, Xu B, Cojocari D, McGuigan AP (2018). A three-dimensional engineered heterogeneous tumor model for assessing cellular environment and response. Nat Protoc 13: 1917. [CrossRef]

- $\quad$ Sittampalam GS, Coussens NP, Brimacombe K, Grossman A, Arkin M, Auld D, Chung TDY (2004). Measurement of $\beta$-Arrestin Recruitment for GPCR Targets--Assay Guidance Manual.

- $\quad$ Spanos GA, Wrolstad RE (1990). Influence of processing and storage on the phenolic composition of Thompson Seedless grape juice. J Agric Food Chem 8: 1565-1571. [CrossRef]

- Sreekanth D, Arunasree MK, Roy KR, Chandramohan Reddy T, Reddy G V, Reddanna P (2007). Betanin a betacyanin pigment purified from fruits of Opuntia ficus-indica induces apoptosis in human chronic myeloid leukemia Cell line-K562. Phytomedicine 14: 739-746. [CrossRef]

- $\quad$ Sun J, Chu Y-F, Wu X, Liu RH (2002). Antioxidant and antiproliferative activities of common fruits. J Agric Food Chem 50: 7449-7454. [CrossRef]

- $\quad$ Sun W, Tao Y, Yu D, Zhao T, Wu L, Yu W (2018). Myricetin exerts potent anticancer effects on human skin tumor cells. Trop J Pharm Res 17: 1067. [CrossRef]

- Üstündağ-Okur N, Gökçe EH, Bozbıyık Di, Eğrilmez S, Ertan G, Özer Ö (2015). Novel nanostructured lipid carrier-based inserts for controlled ocular drug delivery: evaluation of corneal bioavailability and treatment efficacy in bacterial keratitis. Expert Opin Drug Deliv 12: 1791-1807. [CrossRef]

- $\quad$ Zhang J, Ren L, Yang X, White M, Greenhaw J, Harris T, Shi Q (2018). Cytotoxicity of 34 FDA approved small-molecule kinase inhibitors in primary rat and human hepatocytes. Toxicol Lett 291: 138-148. [CrossRef] 